\title{
A new design for honey bee hoarding cages for laboratory experiments
}

\author{
Angela Köhler ${ }^{1,2 *}$, Susan W Nicolson ${ }^{1}$ and Christian W W Pirk ${ }^{1}$ \\ ${ }^{1}$ Department of Zoology and Entomology, University of Pretoria, Pretoria 0002, South Africa. \\ ${ }^{2}$ Present address: Laboratory for Fundamental and Applied Research in Chemical Ecology (FARCE), University of Neuchâtel, \\ Rue Emile-Argand 11, 2000 Neuchâtel, Switzerland.
}

Received 13 January 2012, accepted subject to revision 4 December 2012, accepted for publication 21 January 2013

*Corresponding author: Email: angela.koehler@unine.ch

Keywords: Apis mellifera scutellata, polycarbonate cage, group size, feeders, honeycomb

Honey bees are the subject of research around the world due to their great economic importance and current population declines

(vanEngelsdorp and Meixner, 2010). Many studies cannot be conducted at the colony level. Controlled cage experiments provide insight into behavioural interactions (Elzen et al., 2001), diseases (Martín-Hernández et al., 2009), nutritional requirements (Altaye et al., 2010) and effects of insecticides and genetically engineered plants on these important pollinators (Malone et al., 1999; Medrzycki et al., 2003).

Honey bees have been kept in hoarding cages of various materials and sizes (reviewed in Williams et al., 2013). Wood is widely used, with mesh for ventilation, and glass fronts for observations (Altaye et al., 2010; Malone et al., 1999). Others have used Plexiglas ${ }^{\circledR} /$ Perspex $^{\circledR}$ (polymethyl methacrylate) cages (Grozinger et al., 2003; Medrzycki et al., 2003), wire mesh cylinders and Petri dishes (Melathopoulus et al., 2000). Disposable alternatives include plastic cups (Evans et al., 2009; Iwasa et al., 2004) and cardboard boxes (Moncharmont et al., 2003; Picard-Nizou et al., 1997). Research papers often lack detail on cage design, making it difficult to replicate the experimental conditions. Here we propose a durable cage design that has been successfully tested in our laboratory.

We recommend constructing cages from polycarbonate (PC), which is very break-resistant. Transparent PC is ideal for observations and video recordings, an obvious advantage over wood. PC is resistant to various foodstuffs, such as sugars and oils. It can withstand temperatures of $120^{\circ} \mathrm{C}\left(40^{\circ} \mathrm{C}\right.$ higher than polymethyl methacrylate) and can therefore be autoclaved between trials, which is particularly important for studies on bee pathogens. Ethanol can also be used for sterilisation. Resistance to sodium hypochlorite is limited, although bleach commonly contains $<8 \%$ sodium hypochlorite, which PC can endure. It is important to note that PC is not resistant to acetone, a solvent often used in toxicological studies. Its otherwise good resistance and durability makes PC a suitable material for hoarding cages, although potential negative effects of PC on honey bees remain to be investigated.
The bottom of the hoarding cage consists of wire-mesh for ventilation; this should be made from a rust-resistant material (e.g. stainless steel) to withstand high humidity. Cages should be assembled using screws: glue may contain toxic ingredients, and may gradually dissolve when exposed to high temperature and humidity.

An outside measurement of $11.5 \times 10 \times 14 \mathrm{~cm}$ for the cage is ideal to sustain groups of 100 workers, but leaves space for $>300$ if needed. Many experiments have used only 20-60 workers per cage (Evans et al., 2009; Martín-Hernández et al., 2009). However, larger groups are preferred because queens mate with up to 60 drones (Adams et al., 1977), so not all patrilines may be represented in a cage with too few bees, resulting in genetic differences between cages from the same colony. Furthermore, the fewer bees there are in a group, the less they act as a social unit. Darchen (1957), for instance, showed that comb construction only starts in groups of $75-100$ workers.

The top and two sides of the cage consist of $10 \mathrm{~mm}$ thick PC for stability (Fig. 1). Thin PC slides ( $3 \mathrm{~mm}$ ) in grooves serve to close the front and back of the cage and can be lifted for access to the inside. The wire-mesh bottom slides into grooves. It is convenient to have a second pair of grooves cut above those for the wire-mesh, so that the back slide can be lifted for insertion of a second base before removing the first for quick removal of dead workers.

An additional small PC piece with openings sits underneath the front slide. Feeders made from plastic test tubes with screw-on lids are inserted horizontally. Feeder pieces can be exchanged to accommodate different numbers and sizes of feeders. The hole for feeding cut into the plastic tube should be no bigger than $1 \times 0.3 \mathrm{~cm}$ for liquids, in order to minimize evaporation and prevent drowning of the bees. Larger feeding holes can be used for solid diets so that the bees can walk into the feeder to collect the food.

Groups of 100 Apis mellifera scutellata workers provided with honey comb $(5 \times 5 \mathrm{~cm})$ survive better than those given a wax foundation of the same size (Fig. 2). There are two reasons why the presence of a 


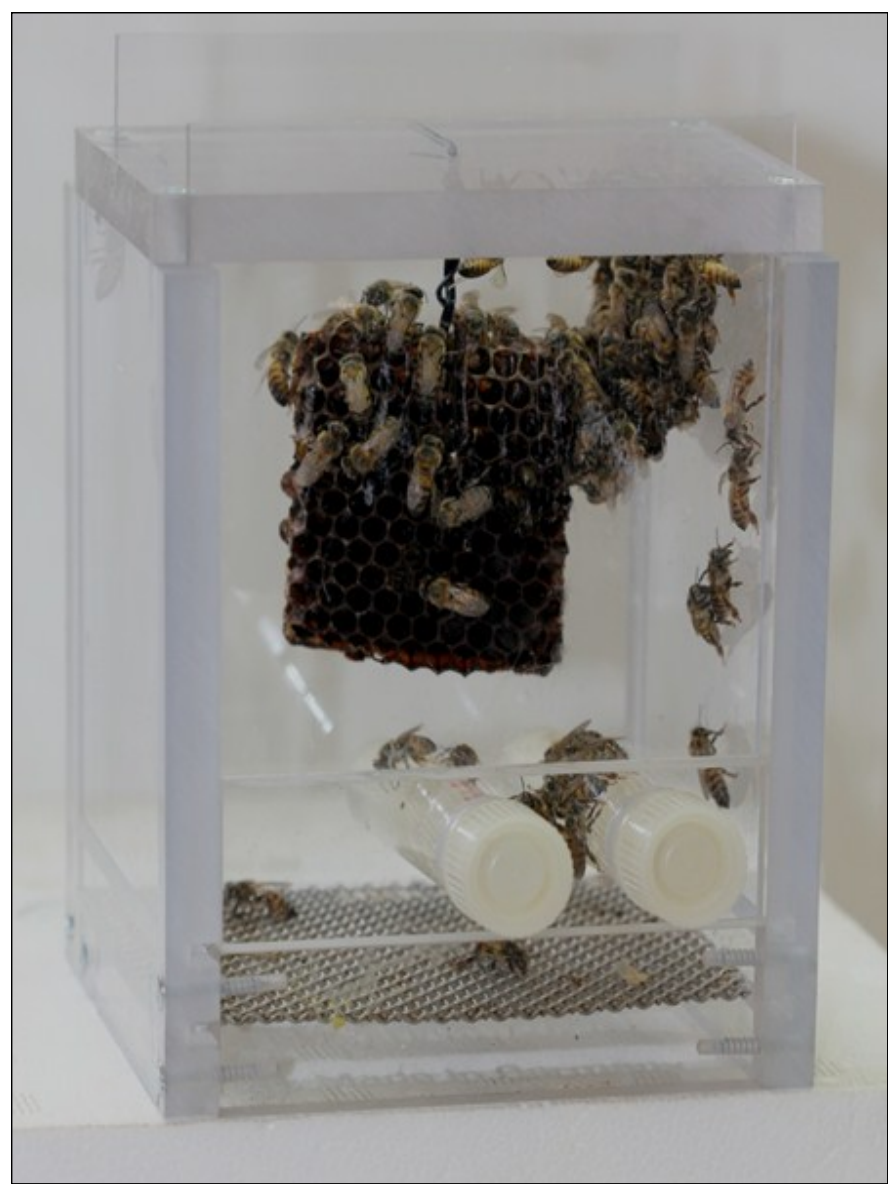

Fig. 1. The honey bee hoarding cage made from polycarbonate.

Photograph taken by A.K. Switala

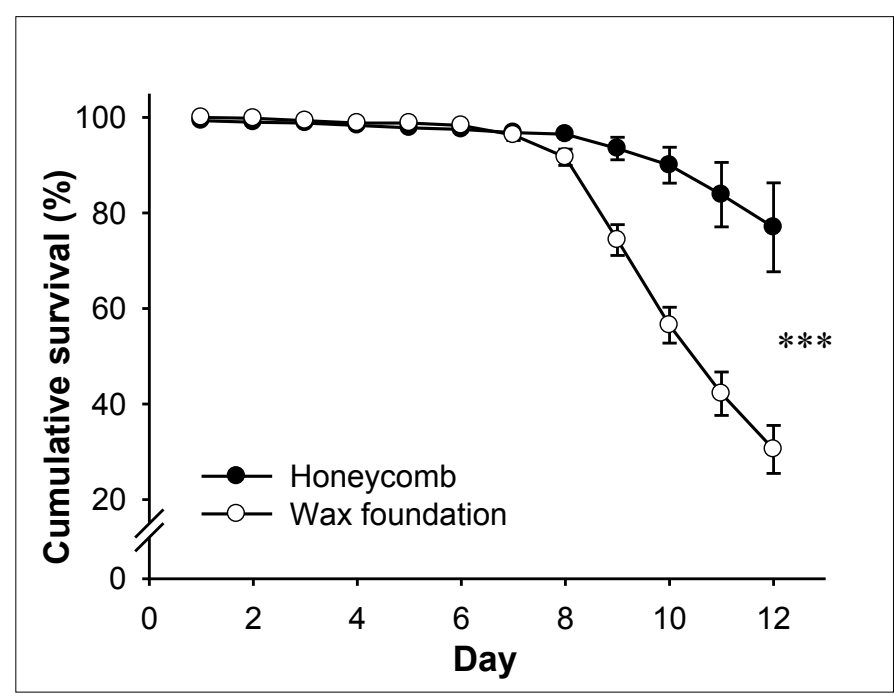

Fig. 2. Survival of caged $A$. m. scutellata workers, incubated at $34^{\circ} \mathrm{C}$ and on a $0.63 \mathrm{M}$ sucrose diet, when provided with either a piece of honeycomb or wax foundation ( $N=12$ cages from six colonies; mean $\pm \mathrm{SE}$ ). Survival was lower in workers with wax foundation

(Gehan's Wilcoxon; $Z=16.03, * * * P<0.001$ ).

\section{Acknowledgments}

This work was funded jointly by a grant from BBSRC, Defra, NERC, the Scottish Government and the Wellcome Trust, under the Insect Pollinators Initiative (BBI000968/1). We thank Kendall Crous and Timothy Richardson for constructing and assembling the cages.

comb may improve survival. Firstly, young bees keep warm by crawling inside the cells, as endothermic heat production only develops in workers older than two days (Stabentheiner et al., 2010). Secondly, honey bees store sugar solution in the comb, which is later consumed. Honey bees do not defecate inside the cage and may benefit from ingesting a more concentrated diet after storage. The stored solution may further assist with humidity regulation.

Different laboratories have developed various cage designs for controlled honey bee experiments. We feel that standardization of maintenance cages would increase comparability between studies. We have proposed a robust, re-usable cage design that can sustain honey bees over several weeks, with easy feeder access and removal of dead individuals. Its transparency allows for behavioural observations. Given the cost of polycarbonate, the proposed hoarding cage is perfect for longer-term experiments, while inexpensive disposable cages may be favoured for short experiments. The advantage of the polycarbonate cage is that it is long-lasting due to the resistant material and can be autoclaved and disinfected to prevent cross-contamination.

\section{References}

ADAMS, J; ROTHMAN, E D; KERR, W E; PAULINO, Z L (1977)

Estimation of the number of sex alleles and queen matings from diploid male frequencies in a population of Apis mellifera. Genetics 86: 583-596.

ALTAYE, S Z; PIRK, C W W; CREWE, R M; NICOLSON, S W (2010)

Convergence of carbohydrate-biased intake targets in caged worker honey bees fed different protein sources. Journal of Experimental Biology 213: 3311-3318.

http://dx.doi.org/10.1242/jeb.046953

DARCHEN, R (1957) La reine d'Apis mellifica les ouvrières pondeuses et les constructions cirières. Insectes Sociaux 4: 321-325.

ELZEN, P J; BAXTER, J R; NEUMANN, P; SOLBRIG, A J; PIRK, C W W; HEPBURN, H R; WESTERVELD, D; RANDALL, C (2001) Behaviour of African and European subspecies of Apis mellifera toward the small hive beetle, Aethina tumida. Journal of Apicultural Research 40: 40-41. 
EVANS, J D; CHEN, Y P; PRISCO, G D; PETTIS, J; WILLIAMS, V (2009) Bee cups: single-use cages for honey bee experiments. Journal of Apicultural Research 48: 300-302.

http://dx.doi.org/10.3896/IBRA.1.48.4.13

GROZINGER, C M; SHARABASH, N M; WHITFIELD, C W; ROBINSON, G E (2003) Pheromone-mediated gene expression in the honey bee brain. Proceedings of the National Academy of Sciences 100: 14519-14525. http://dx.doi.org/10.1073/pnas.2335884100

IWASA, T; MOTOYAMA, N; AMBROSE, J T; ROE, R M (2004) Mechanism for the differential toxicity of neonicotinoid insecticides in the honey bee, Apis mellifera. Crop Protection 23: 371-378. http://dx.doi.org/10.1016/j.cropro.2003.08.018

MALONE, L A; BURGESS, E P J; STEFANOVIC, D (1999) Effects of a Bacillus thuringiensis toxin, two Bacillus thuringiensis biopesticide formulations, and a soybean trypsin inhibitor on honey bee (Apis mellifera L.) survival and food consumption. Apidologie 30: 465-473. http://dx.doi.org/10.1051/apido:19990601

MARTÍN-HERNÁNDEZ, R; MEANA, A; GARCÍA-PALENCIA, P; MARÍN, P; BOTÍAS, C; GARRIDO-BAILÓN, E; BARRIOS, L; HIGES, M (2009) Effect of temperature on the biotic potential of honey bee microsporidia. Applied and Environmental Microbiology 75: 2554-2557. http://dx.doi.org/10.1128/AEM.02908-08 MEDRZYCKI, P; MONTANARI, R; BORTOLOTTI, L; SABATINI, A G; MAINI, S; PORRINI, C (2003) Effects of imidacloprid administered in sub-lethal doses on honey bee behaviour. Laboratory tests. Bulletin of Insectology 56: 59-62.

MELATHOPOULUS, A P; WINSTON, M L; WHITTINGTON, R; SMITH, T; LINDBERG, C; MUKAI, A; MOORE, M (2000) Comparative laboratory toxicity of Neem pesticides to honey bees (Hymenoptera: Apidae), their mite parasites Varroa jacobsoni (Acari: Varroidae) and Acarapis woodi (Acari: Tarsonemidae), and brood pathogens Paenibacillus larvae and Ascophaera apis. Journal of Economic Entomology 93: 199-209.

http://dx.doi.org/10.1603/0022-0493-93.2.199
MONCHARMONT, F-X D; DECOURTYE, A; HENNEQUET-HANTIER, C; PONS, O; PHAM-DELÈGUE, M-H (2003) Statistical analysis of honey bee survival after chronic exposure to insecticides. Environmental Toxicology and Chemistry 22: 3088-3094.

http://dx.doi.org/10.1897/02-578

PICARD-NIZOU, A L; GRISON, R; OLSEN, L; PIOCHE, C; ARNOLD, G; PHAM-DELÈGUE, M H (1997) Impact of proteins used in plant genetic engineering: toxicity and behavioral study in the honey bee. Journal of Economic Entomology 90: 1710-1716.

STABENTHEINER, A; KOVAC, H; BRODSCHNEIDER, R (2010) Honey bee colony thermoregulation - regulatory mechanisms and contribution of individuals in dependence on age, location and thermal stress. PLOS ONE 5: e8967.

http://dx.doi.org/10.1371/journal.pone.0008967

VANENGELSDORP, D; MEIXNER, M D (2010) A historical review of managed honey bee populations in Europe and the United States and the factors that may affect them. Journal of Invertebrate Pathology 103: S80-S95. http://dx.doi.org/10.1016/j.jip.2009.06.011

WILLIAMS, G R; ALAUX, C; COSTA, C; CSÁKI, T; DOUBLET, V; EISENHARDT, D; FRIES, I; KUHN, R; MCMAHON, D P; MEDRZYCKI, P; MURRAY, T E; NATSOPOULOU, M E; NEUMANN, P; OLIVER, R; PAXTON, R J; PERNAL, S F; SHUTLER, D; TANNER, G; VAN DER STEEN, J J M; BRODSCHNEIDER, R (2013) Standard methods for maintaining adult Apis mellifera in cages under in vitro laboratory conditions. In V Dietemann; J D Ellis; P Neumann (Eds) The COLOSS BEEBOOK, Volume I: standard methods for Apis mellifera research. Journal of Apicultural Research 52(1): http://dx.doi.org/10.3896/IBRA.1.52.1.04 